to speak out their convictions as to the supposed advantages of European medical education when compared with those of our own country.

Permit me to say that my personal experience warrants the full corroboration of the statements made by your correspondente. Familiarity with the teaching of the medical schoole in our Eastern cities, and frequent trips across the A tlantic the last twenty years, during which I studied at the principal European medical centers, have afforded ample opportunity to make comparison which, without any spread-eagleism, I am forced to say is greatly in favor of my native land. Just why any true American should go in to ecstacies over anything German has always been a puzzle to me. While there are many individual Germans whom I respect and admire, candor compels me to say that after much travel around the globe Ger. mans, as a class, are the rudest people I have ever met, and beyond beer and music I found nothing to admire in a country where most things partake of the cheapness and mediocrity of the imported articles labeled in Deutschland gemacht. Dur. ing my stay in that garish but most dull and unattractive city, Berlin, shortly after the Franco-Prussian war, I was constantly taken for ein Britisher, and on witnessing an operation it was a common thing to be told that "they do it better in your country," little knowing that I was from the land of the tabooed pig and apple.

Though devoting a year to the study of German medical nomenclature alone before going abroad, I found it impossible to seize more than a general sense of the lectures attended. The study of German, in view of the enormous growth and great spread of English, is a waste of time only equaled by the German medical journal disease, or the absurdity of expect ing to find in that country what exists in greater perfection in New York, for instance. Indeed, medical education has so advanced in this country of late that it is safe to predict that before many years Europeans will come here for study.

Of course I do not wish to imply that nothing is to be gained by going abroad. If the medical man really wants to learn he will fina London, Paris and Rome the best places, and if interested in neurology, psychiatry or criminal anthropology, he will find Italians in the foremost rank. Every medical man who can afford it should visit Europe, not so much with the expectation of professional benefit as for that accruing from attrition with other minds, the wiping away of numerous cobwebs of prejudice, and the still stronger reason that he will return to his native land a better American.

Irving C. Rosse, M.D., F.R.G.S.

\section{Leprosy in Norway and America.}

Bergen, Norway, Feb. 1, 1898.

To the Editor:-Allow me to make some currections of Dr. Caldwell's article in the number of December 18, which you have sent me. Dr. Caldwell says that in our hospitals for the confinement and treatment of lepers were "domiciled over one thousand unfortunates afflicted with that terrible disease." From where or from whom Dr. Caldwell has obtained this information I can not imagine, for we had last summer not more than about three hundred and fifty lepers in our institutions. Later on Dr. Caldwell says that "I, in my visit to the United States found three cases in the hospitals in Chicago and twice as many in New York, as well as encountered several cases of true leprosy upon the streets of each city, all of whom were treated for lupus, sy philis or some other form of skin disease." I regret if any of my Norwegian colleagues has given such information to Dr. Caldwell. The truth is that in Minnesota I found one case and in the City Hospital in Chicago one case, not of leprosy treated for syphilis, but of syphilis diagnosed as leprosy. Now this is not to be wondered at, when the doctors have no acquaintance with leprosy. You will allow me to tell the incident in the City Hospital in Chicago, where I went. accompanied by my colleague, Dr. Sandberg of Chicago. A young American doctor lod wa to the patient, who was a Dane. I saw at once that the man had no leprosy and asked him in Danish, "When did you get your ehanere?" "Seven or eight months ago," replied the man. The young American. doctor, who understood the word chanere, I suppose, said: "Oh, sir, he does not understand that." "Certainly he understands." said I. "He had his chanere eight monthe ago." "Oh, dear me," saidathe young man.

In the streets of the cities I never faw a leper, and I account for disease not spreading from the leprous immigrants of Wiseonsin, Minnesota and Iowa by the cleanliness of the people. everywhere. I said then and I say still: The first thing a Norwegian peasant, who is not cleanily, learng in America is to. wash himself, and that does great credit to American customs. While writing you I will take the liberty to say some words of Dr. Ashmead's letter in the same number: I will not take up. a discussion of the Leper Conference in Berlin. I. will only say that I still never have seen an instanee of "melancholia of leprosy." This affection is a discovery of Dr. Ashmead, but I regret to say that neither I nor anyone else in Norway has any idea of the existenee of such an affection. One may meet with lepers who are melancholic, of course, but geverally our lepers. are of the same mental disposition as other people, and remarkably seldom we see a depression of their good humor, in spite. of the disease; the reason is that the brain is nover affected in leprosy, and one sees often enough people keep their good: spirits in spite of even more fearful diseases than leprosy. I am, sir, yours respectfully, G. A. Hainsen, M.D.

\section{The Alleged Castration of Squirrels.}

Hudson, Ohio, Feb. 8; 1898.

To the Editor:-In a recent Journal. Dr. Taylor has a communication with this heading "Do adult squirrels castrate each other?" A better heading would be "Do any squirrels castrate each other?"

In Vol. iii, page 646 of Owen's "Anatomy of Vertebrates" you will find a description of the male organs of the rodentia. A mong other things he says: "The testes undergo a periodical increase of size and change of position, passing from the abdomen into a sessile scrotum and being again retracted, after the rut, within the abdomen." This change of position involving the disappearance of these glands, which are very conspicuous during the rutting season, has given origin to the belief that the males were often castrated. The Doctor notes a very significant fact that this supposed castration by another squirrel leaves no visible scar. If a surgeon will perform the operation with his sharpest knife he will leave a scar that will bear witness to his work. Any one who will carefully dissect one of these supposed emasculated males will find the missing testes within the abdomen so reduced in size as to be easily overlooked. M. C. REA.D, M.D.

\section{Physicians Should be Compensated.}

Philadelphia, Pav, Feb. 18, 1898.

To the Editor:-The editorial in the number of your Jorrnat. for February 12 upon the subject of "notification of contagious diseases" is very timely. I have never been able to understand why physicians should be forced to make notification of contagious disease without compensation, as is commonly done in this country. In England physicians are paid two shillings and six pence each time they give notice of a case of contagious. disease in their private practice, and one shilling if the case occurs in a public institution. This is provided by law. It seems contrary to fundamental justice, if not to law, that the medical profession should be made to perform labor without compensation, and I have of ten wondered whether the courts. would not sustain a resistance of it. Respectfully yours, Arthur V. MeIgs, M.D. 